\title{
Analysis of Pyrazine and Volatile Compounds in Cocoa Beans Using Solid Phase Microextraction
}

\author{
Analisis Pirazin dan Senyawa Volatil pada Biji Kakao \\ Menggunakan Mikroekstraksi Fase Padat
}

\author{
M isnawi ${ }^{1 *}$ and A riza Budi Tunjung Sari ${ }^{1)}$
}

\begin{abstract}
Summary
A nalysis of pyrazine and volatile compounds in cocoa beans was done by using solid phase microextraction (SPME), to develop efficient non solvent extraction method. Extraction was carried out in head space technique using stableflex fiber coated with DVB/Carboxen/PDM S applied on manual sampling SPME Holder. Five grams of roasted fermented cocoa bean was processed into butter and placed into $30 \mathrm{ml}$ vial and capped with a rubber septum, then heated at temperature of $70^{\circ} \mathrm{C}$ for $30 \mathrm{~min}$ for the extraction. The fiber then was placed in $G C$ header for desorption and separation. Results of the study showed that the SPME extracted pyrazines were adequate and well detected in a gas chromatography system. Peak area resulted from SPME covered $2.83-5.35 \%$ peak area from syringe, however SPME had comparable ability to syringe in extracting volatile compounds. Five most common pyrazines in cocoa bean aroma were identified, such as 2 methyl pyrazine (2M P); 2.3 and 2.5 dimethyl pyrazine (D M P); and 2,3,5 trimethyl pyrazine (TrMP) and tetramethylpyrazine (TM P). Other corresponding compounds were also detected in cocoa liquor, i.e. alcohols, carboxylic acids, aldehydes, ketons, esters, pyrazines, amines and other volatile compounds and strongly associated to chocolate aroma. The successful extraction of pyrazine and volatile-semi volatile compounds which contribute to chocolate aroma indicates SPM E is applicable in flavor analysis.
\end{abstract}

Key words: Cocoa bean, flavour, pyrazine, solid-phase microextraction, head space, extraction, gas chromatography, maillard.

\section{Ringkasan}

Analisis pirazin dan senyawa volatil pada biji kakao dilakukan dengan perangkat mikroekstraksi fase padat (solid phase micro extraction, SPME), untuk mengembangkan metode ekstraksi tanpa pelarut yang efisien. Perangkat SPME dilengkapi fiber stableflex dengan polimer DVB/C arboxen/PDMS yang menjerap senyawa volatil di area headspace. Biji kakao terfermentasi disangrai dan diambil lemaknya untuk ditempatkan dalam botol bertutup septa. Sampel dipanaskan pada suhu $70^{\circ} \mathrm{C}$ dan serat SPME ditusukkan menembus septa untuk mengekstrak senyawa volatil dari lemak kakao selama 30 menit. Senyawa volatil lemak kakao akan dijerap oleh serat SPME dan dilepaskan kembali untuk analisis kromatografi gas. Penelitian menunjukkan pirazin dan senyawa volatil yang diekstrak oleh serat SPME dapat terdeteksi dengan baik oleh kromatografi gas. Area puncak yang dihasilkan SPME meliputi 2,83-5,35\% dari area puncak yang dihasilkan

Naskah diterima (received) 2 D esember 2010, di setujui (accepted) 24 M aret 2010.

1) Pusat Penelitian Kopi dan K akao Indonesia, JI. PB. Sudirman N 0. 90, Jember, Indonesia.

*) Alamat penulis (Corresponding Author): misnawi@yahoo.com 
syringe, kendati demikian kemampuan ekstraksi SPME dapat disetarakan dengan syringe. Lima jenis pirazin yang sering terdapat di biji kakao telah diidentifikasi, meliputi metil pirazin (2MP); 2,3 dan 2,5-dimetilpirazin (DMP); dan 2,3,5 trimetilpirazin (TrMP) dan tetrametil pirazin (TMP). Senyawa lainnya juga terdeteksi meliputi alkohol, asam karboksilat, aldehida, keton, ester, pirazin, amin dan senyawa volatil lainnya, dan diketahui erat kaitannya dengan aroma khas cokelat. Keberhasilan SPME dalam ekstraksi pirazin dan senyawa volatilsemi volatil yang berperan penting dalam pembentukan aroma cokelat menandakan SPME dapat digunakan lebih lanjut untuk analisis citarasa.

\section{INTRODUCTION}

Pyrazines ( 1,4 diazines) in roasted cocoa bean contribute to a pleasant aroma of chocolate, and associate with good quality of roasted cocoa bean perception. Large number of pyrazines have been identified in cocoa and are considered extremely important in cocoa flavor (Brunetto et al., 2009; Frauendorfer \& Schieberle, 2008; $\mathrm{K}$ rings et al., 2006; Bonvehi \& Coll, 2002; Counet et al., 2002; Jinap et al., 1998). Detection of volatile compounds including pyrazine has been developed using gas chromatography which requires extraction of those compounds from solid or liquid sample. Schultz et al. (1977) developed a method of extraction using simultaneous distillation and extraction (SDE), in which sample is water-steamed resulting evaporation of volatile compounds which then being captured by certain solution and concentrated prior to syringe injection into $\mathrm{GC}$ system. This SDE-syringe method involves high temperature to extract and move the volatile compound into trapping solution which could detriment the nature of pyrazine. Since pyrazines are product of heating process, bias in analysis could be occurred due to uses of high temperature during steam distillation.

Solid phase microextraction (SPME) is developed to allow extraction of volatile compounds without use of any solvent. SPM E is a solventless extraction technique introduced by Berlardi \& Pawliszyn (1989), which binds volatiles on a silica fiber coated by polymer in headspace area of sample (Berlardi \& Pawliszyn, 1989). Exposing fiber at headspace area ensures that only volatile compounds reach and contact to fiber. Extractions can be conducted in room temperature (Vazquez-Landaverde et al., 2008; M arsili, 2002), but moderate heat of ten increase volatility (Ducki et al., 2008). Trapped volatile then was released in the GC system during injection through desorption mechanism (Pawliszyn et al., 1997).

SPM E differs due to its type of fibers; polar, non-polar and bipolar fibers. Each type of fiber adsorbs different type of compounds. Polar fiber may be coated by polyacrylate (PA) (Shirey, 1999) or carbowax-divinylbenzene (CW-DV B) (Shirey \& Sidisky, 1999). Nonpolar fiber may be constructed of polydimethyl siloxane (PDM S). While bipolar fibers are combination between polar and nonpolar polymer. Bipolar fiber could capture larger spectrum of compounds and could be developed from materials of polydimethylsiloxane-divinylbenzene (PDM SDVB) or Carboxen-PDM S (Shirey \& Sidisky, 1999).

This research investigated analysis of pyrazine and volatile compounds of cocoa beans extracted by SPM E and evaluated toward SDE-syringe extraction. A nalysis was brought by gas chromatography-mass spectrometry, focusing on pyrazine analysis especially 2-methylpyrazine (2-MP); 
2,5-dimethylpyrazine $(2,5 D M P) ; 2,3-$ dimethylpyrazine (2,3-DM P); 2,3,5-trimethylpyrazine (TrMP) and tetramethylpyrazine (TM P).

\section{MATERIAL AND METHODS}

C ocoa beans used were fermented bulk cocoa beans obtained from Post Harvest L aboratory of Indonesian C offee and Cocoa R esearch Institute (ICCRI). The beans were roasted at temperature of $150^{\circ} \mathrm{C}$ for $45 \mathrm{~min}$ and manually processed for shell removal. A quantity of roasted beans was pressed to collect the butter for pyrazine analysis, while the other was ground to obtain cocoa liquor for volatile compounds analysis.

Gas chromatography system consisted of Shimadzu GC-2010 equipped with Rtx-1 ( $100 \%$ dimethyl polisiloxane) column and flame ionization detector for pyrazine analysis, and mass spectrometry for volatile compounds analysis. Bipolar fiber PDM S-DVB SPM E from Supelco was used for extraction.

\section{M ethod of extraction}

Referring to successful pyrazine extraction from peanut butter (Supelco, 1998), this study used cocoa butter as the base of pyrazines extraction. Three $30 \mathrm{~mL}$ vials, each contained five grams of roasted fermented cocoa butter and capped with a rubber septum were immersed in the waterbath. To observe effect of heat to volatile compounds extraction, immersion was prepared at temperatures of $50^{\circ} \mathrm{C}, 60^{\circ} \mathrm{C}$ and $70^{\circ} \mathrm{C}$ respectively. The vial was heated for $30 \mathrm{~min}$ for the extraction. The fiber was then placed in GC injector for desorption and separation in capillary column.

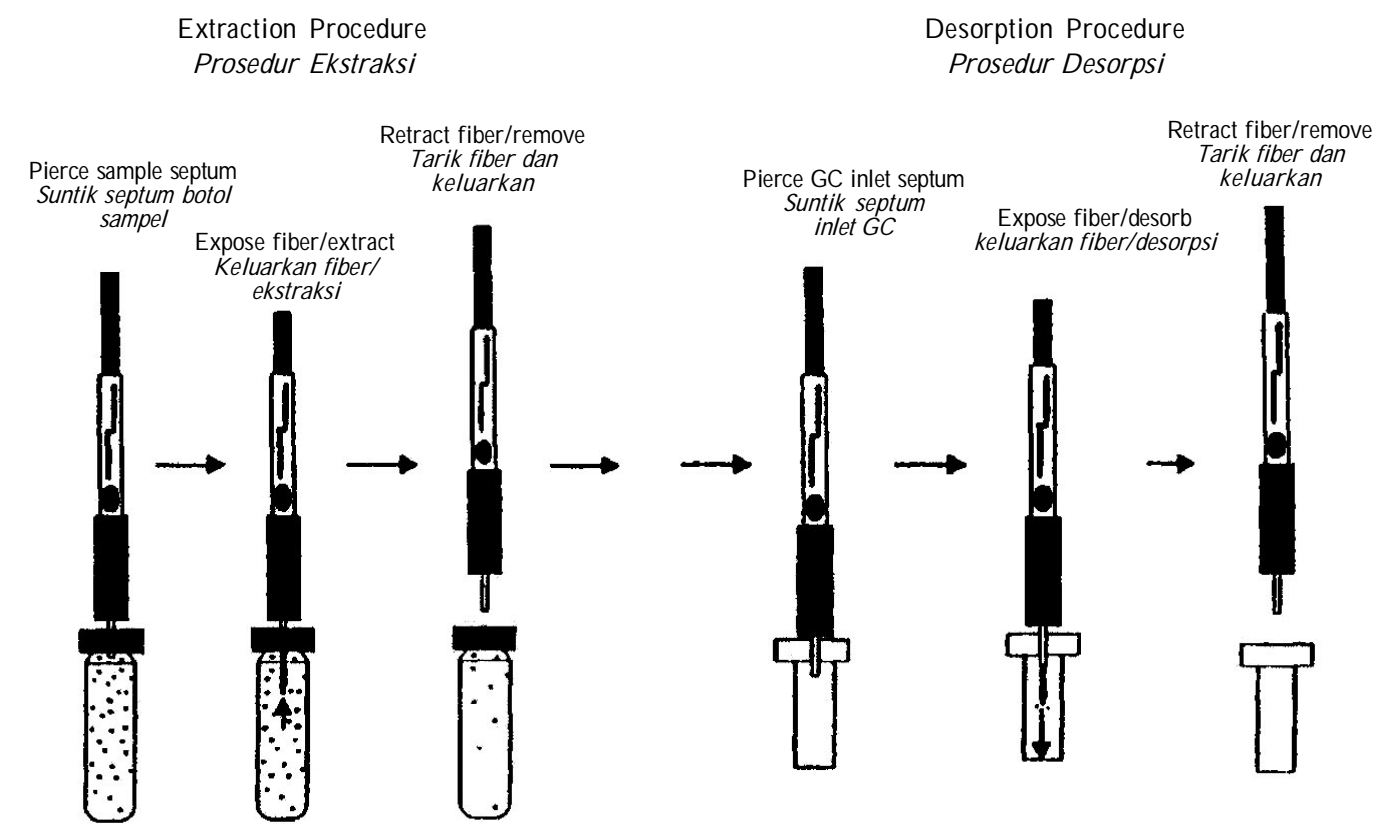

Figure 1. Mechanism of extraction and desorption of SPME.

Gambar 1. Mekanisme ekstraksi dan desorpsi SPME. 
Table 1. GC conditions applied in Supelco (1998) and M isnawi et al. (2004) pyrazines detection and modified methods

Tabel 1. Parameter kromatografi gas berdasarkan metode Supelco (1998) dan M isnawi et al. (2004)

\begin{tabular}{|c|c|c|c|}
\hline $\begin{array}{l}\text { Properties } \\
\text { Parameter }\end{array}$ & Supel co (1998) & M isnawi et al. (2004) & M odified \\
\hline $\begin{array}{l}\text { Sample preparation and } \\
\text { injection } \\
\text { Penyiapan contoh dan } \\
\text { injeksi }\end{array}$ & $\begin{array}{l}\text { Headspace SPM E- } \\
\text { SPME }\end{array}$ & $\begin{array}{l}\text { Steam Destillation- } \\
\text { SPME }\end{array}$ & $\begin{array}{l}\text { H eadspace SPM E- } \\
\text { SPME }\end{array}$ \\
\hline \multicolumn{4}{|c|}{ Injector Parameter (Parameter infektor) } \\
\hline Inlet Liner & $0.75 \mathrm{~mm}$ & $4 \mathrm{~mm}$ & $0.75 \mathrm{~mm}$ \\
\hline Temperature (Suhu) & $270^{\circ} \mathrm{C}$ & $200^{\circ} \mathrm{C}$ & splitless $/ 260^{\circ} \mathrm{C}$ \\
\hline Pyrazine source (Sumber pirazin) & Peanut & Cocoa bean & Cocoa butter \\
\hline Column (Kolom) & $\begin{array}{l}\text { Supelcowax } 1030 \mathrm{~m} \mathrm{x} \\
0.25 \mathrm{~mm} \text { ID x } 0.25 \mu \mathrm{m}\end{array}$ & $\begin{array}{l}\mathrm{HP}-20 \mathrm{M} 50 \mathrm{~m} \times \\
0.32 \mathrm{~mm} \text { ID } \times 0.3 \mu \mathrm{m}\end{array}$ & $\begin{array}{l}\text { Rtx-1(D imethyl } \\
\text { Polysiloxane) } 30 \mathrm{~m} \times \\
\text { I,25 mm ID x } 0.25 \mu \mathrm{m}\end{array}$ \\
\hline \multicolumn{4}{|l|}{ Oven (Oven) } \\
\hline Initial temperature (Suhu awal) & $40^{\circ} \mathrm{C}$ & $60^{\circ} \mathrm{C}$ & $60^{\circ} \mathrm{C}$ \\
\hline Equilibrium (Keseimbangan) & $5 \mathrm{~min}$ & $3 \mathrm{~min}$ & $3 \mathrm{~min}$ \\
\hline Rate (Laju) & $4^{\circ} \mathrm{C} / \mathrm{min}$ & $5^{\circ} \mathrm{C} / \mathrm{min}$ & $5^{\circ} \mathrm{C} / \mathrm{min}$ \\
\hline Final temperature (Suhu akhir) & $230^{\circ} \mathrm{C}$ & $180^{\circ} \mathrm{C}$ & $200^{\circ} \mathrm{C}$ \\
\hline Hold & - & $5 \mathrm{~min}$ & - \\
\hline D etector (D etektor) & $\begin{array}{l}\text { Ion trap mass spectro- } \\
\text { meter, selected ions } \\
\text { used for quantification } \\
\text { Spectrometry }\end{array}$ & $\begin{array}{l}\text { Flame Ionization } \\
\text { Detector (FID) }\end{array}$ & $\begin{array}{l}\text { Flame Ionization } \\
\text { D etector (FID) } \\
\text { for pyrazine analysis, M ass } \\
\text { (Shimadzu GC-M S 2010) }\end{array}$ \\
\hline
\end{tabular}

\section{GC Conditioning}

Gas chromatography adjustment used in this study was obtained from several preliminary experiments to obtain the best response of the GC system on pyrazine compounds separation and detection. Two methods were used as references i.e.a method for peanut pyrazine detection with SPM E extraction from Supelco (1998) and GC condition for cocoa pyrazine detection with SDE (simultaneous distillation extraction) developed by M isnawi et al. (2004). Those methods were combined to obtain a new detection method as described in Table 1.

\section{RESULTS AND DISC USSION Performance of SPME}

The bipolar fiber PDM S-DV B used in this experiment was able to extract pyrazine from cocoa butter and release volatile com- pounds for further analysis in GC. Supelco (1998) recommends using polar fiber for optimum extraction of polar compounds and vice versa. Bipolar fiber is expected to provide larger spectrum of adsorption than the other two types of fiber. PDM S-DV B bipolar fiber was employed to obtain most of pyrazine in cocoa butter.

The extraction of both pyrazine and volatile compounds in fiber was through adsorption mechanism. There are two possibilities of how compounds attached on the fiber, by absorption or adsorption. A bsorption mechanism is when compounds bind chemically with the matrix, while in adsorption mechanism, compounds only adhere on the surface of matrix. A fter being adsorbed onto fiber surface, volatile compounds subsequently were released by certain desorption procedure.

Extraction of analytes will continue running until the fiber reach its equilibrium state. At equilibrium point, concen- 

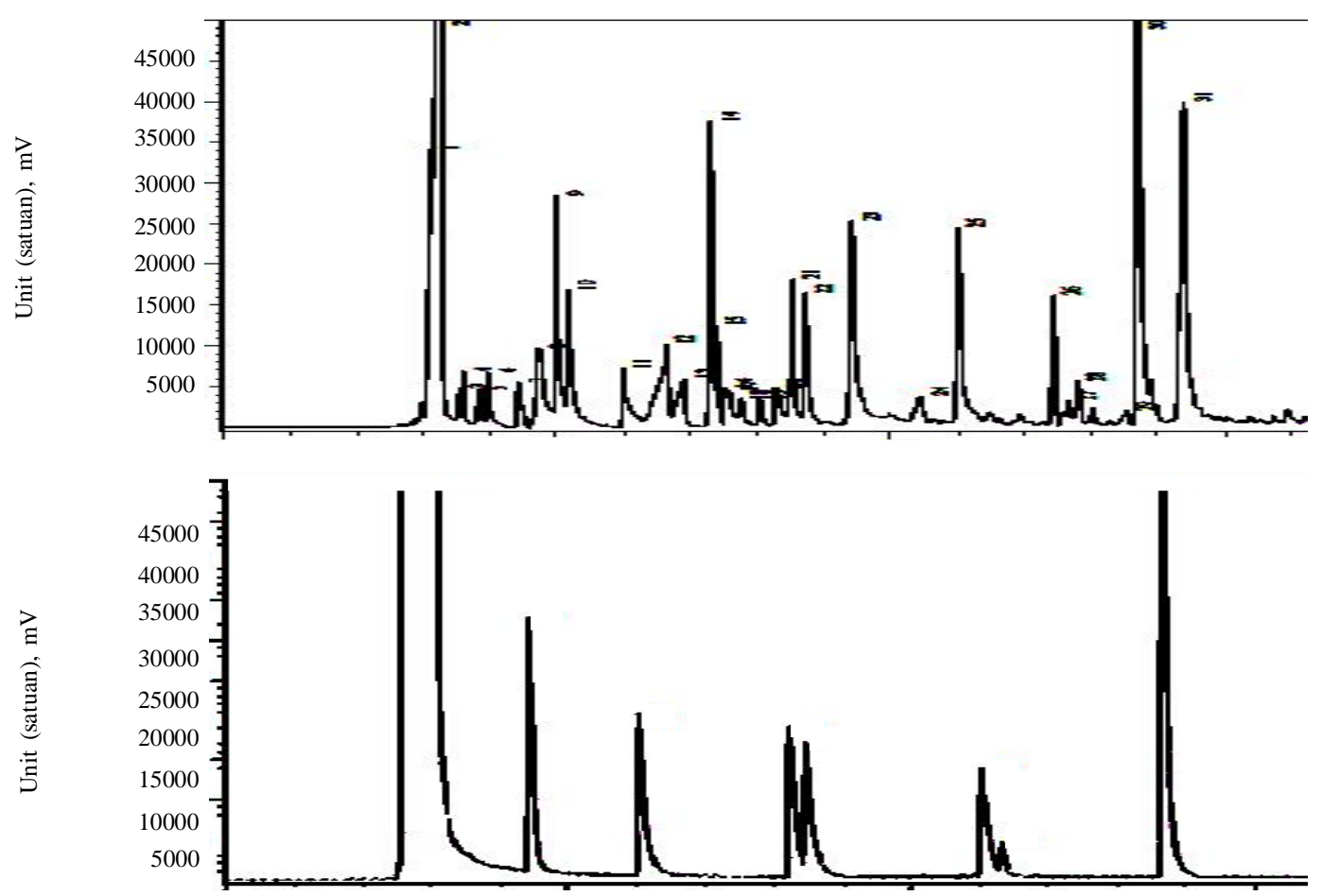

Figure 2. Chromatogram of volatile compounds extracted from cocoa butter by using SPME (above) and seven pyrazine standards (below).

Gambar 2. Kromatogram senyawa volatil yang diekstrak dari lemak kakao menggunakan SPME (atas) dan senyawa pirazin yang dijadikan standar (bawah).

tration of analyte in the fiber is equal with concentration of analyte in sampling area, Further exposion will result in minor effect, since the fiber would meet its limit of trapping. Equilibrium state usually accomplished in 30 minutes (da Silva, 2008; M arsili, 2002).

The extraction process was followed by injection to GC instrument. There are two methods of setting $G C$ parameters, the first developed by Supelco and the second developed by M isnawi et al. (2004). Supelco has successfully analyzed pyrazines from peanut butter, while M isnawi et al. (2004) have analysed pyrazine from cocoa bean by applying SDE extraction.

A djustment made to those methods, injector temperature was referred to Supelco methods that apply injector temperature of $230^{\circ} \mathrm{C}$. Injector temperature above $200^{\circ} \mathrm{C}$ was recommended to accommodate desorption of analyte from fiber. This is also confirmed by works of Kumazawa et al. (1999), Vilchez et al. (2001) and Perraudine et al. (2006) that applied injector temperature over than $200^{\circ} \mathrm{C}$. Therefore column constructed of dimethylpolisiloxane-crossbond were applied due to its ability to retain high temperature up to $300^{\circ} \mathrm{C}$.

The modification allowed better component separation and took relatively shorter time. Chromatogram of the modified method in the volatile compounds separation is shown in Figure 2. Standard solution consisting of 2-methylpyrazine (2M P); 2,5 dimethylpyrazine (2,5 DM P); 2,3 dimethylpyrazine $(2,3$ D M P ); 2, 3,5 trimethylpyrazine and 2,3,5,6 tetra-

Pelita Perkebunan, Volume 27, Nomor 1, Edisi April 2011 
methylpyrazine $(2,3,5,6$ TM P) were extracted by SPM E apparatus. Beside pyrazines, numbers of volatile and semi-volatile compounds also appeared, such as carboxilyc acid, hydrocarbons, alcohols, aldehides and esters.

This result showed that the developed method was able to detect most of pyrazine compound presented in roasted cocoa bean. The 2,5-DM P, 2.3-DM P, 2,3,5-TrM P and tetramethylpyrazine were detected at retention time of $8.539,8.733,11.088$ and 13.715 minutes, respectively. Due to its molecular weight which affects volatility, 2M P was among the compounds identified in early minutes, along with simple carboxylic acids, aldehyde and alkane. Detection of 2M P was followed by 2,5 DM P; 2.3 DM P; 2,3,5 TM P and acetylpyrazine.

Compared to SDE-syringe application, concentration of extracted compounds using SPM E was much smaller. Peak area resulted from SPM E analysis covered 2.83$5.35 \%$ of peak area resulted from syringe (Figure 3). When sampling was carried out using syringe, all molecules in sample was inhaled into the syringe. While in extraction carried out using SPM E, the molecules will be trapped in limited amount. A dsorbing rate of SPM E decreased as the concentration of analyte increased (Figure 4). This occurred as the fiber became saturated and was unable to trap additional molecules. This saturation stage suggested equilibrium state that is normally accomplished in 30 minutes.

The molecules adsorbed in various quantity, depends on thickness of polymer as well as their own physical properties such as polarity and boiling point. As being shown in Figure 5 , peak area resulted by syringe extraction shows that $2 \mathrm{MP}$ has larger peak area then 2,3 DM P > 2,5 DM P $>2,3,5 \mathrm{TrM}$ P. While peak area resulted from SPM E shows different sequence, where peak area of 2,3 DMP $>2,3,5 \mathrm{TrMP}>2$ $M P>2,5 D M P$.

The difference might be due to compound volatility, and also due to difference in polarity. Interaction between compounds and SPME polymer was suggested to occurr within polarity variations. M atrix effect has been an issue related to the use of SPME, which affects extraction-desorption performance of SPME fiber (Górecki et al., 1999). However by specifying target compound and selecting suitable fiber, this matrix effect could be minimized.

\section{E ffect of extraction temperature}

Extraction temperature was set at three levels, $50^{\circ} \mathrm{C}, 60^{\circ} \mathrm{C}$ and $70^{\circ} \mathrm{C} . \mathrm{GC}$ analysis detected 27 compounds, 33 compounds and 34 compounds, respectively for extraction temperature of $50^{\circ} \mathrm{C}, 60^{\circ} \mathrm{C}$ and $70^{\circ} \mathrm{C}$. Temperature of $70^{\circ} \mathrm{C}$ facilitated liberation of volatile compounds. At this condition, cocoa butter as the matrix melts down and provides ways for volatile compounds to evaporate (F igure 6).

Extraction temperature also affected peak area performed by volatile compounds. Compounds of 3-methyl-butyl-acetate; 2,5-dimethyl pyrazine and 2,3-dimethylpyrazine were found in larger peak area at temperature $50^{\circ} \mathrm{C}$, and decreasing as the extraction temperature raised. However benzaldehyde, phenylethyl alcohol and 2phenylethyl ester showed inclination in peak area at extraction temperature $60^{\circ} \mathrm{C}$ and $70^{\circ} \mathrm{C}$. This result indicated that moderate heat facilitated more deliberation of compounds in high molecular weight.

$H$ eat available in the extraction phase also supplies energy to molecules to reach its boiling point. 2-methyl pyrazine under $76 \mathrm{cmHg}$, has boiling point of $135^{\circ} \mathrm{C} ; 2,3-$ dimethyl pyrazine and 2,5-dimethyl 




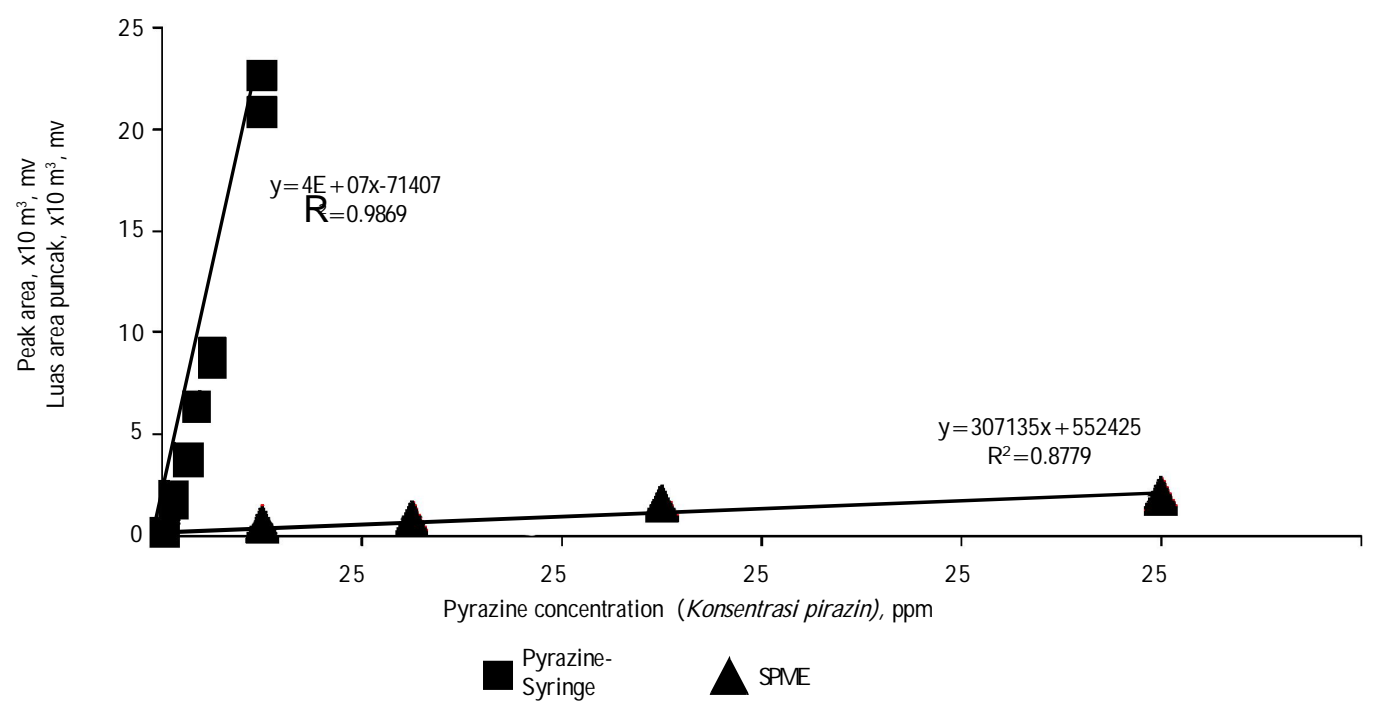

Figure 3. Comparison of peak area resulted from syringe extraction and SPME

Gambar 3. Perbandingan luas area puncak yang dihasilkan ekstraksi syringe dan SPME.

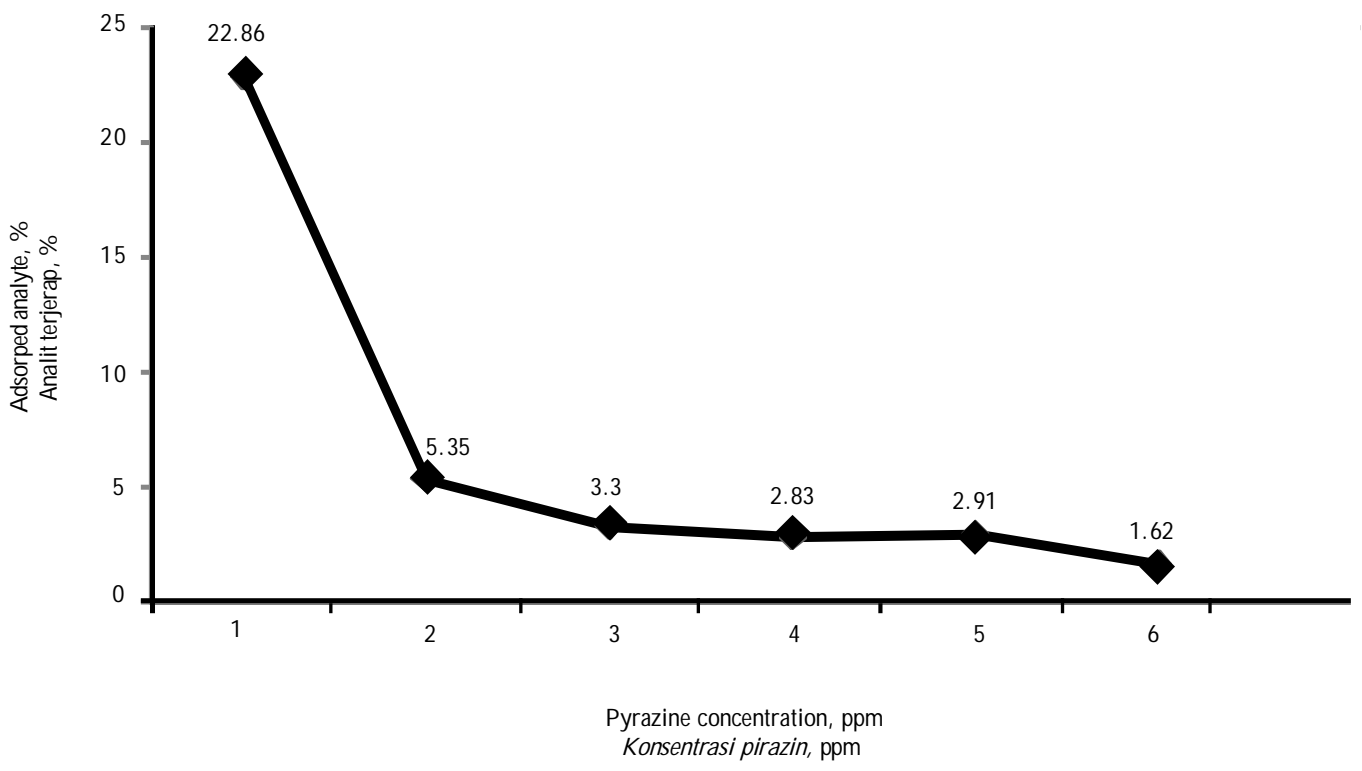

Figure 4. Effect of pyrazine concentration on the percentage of adsoped analyte. Gambar 4. Pengaruh konsentrasi pirazin terhadap persentase analit terjerab. 


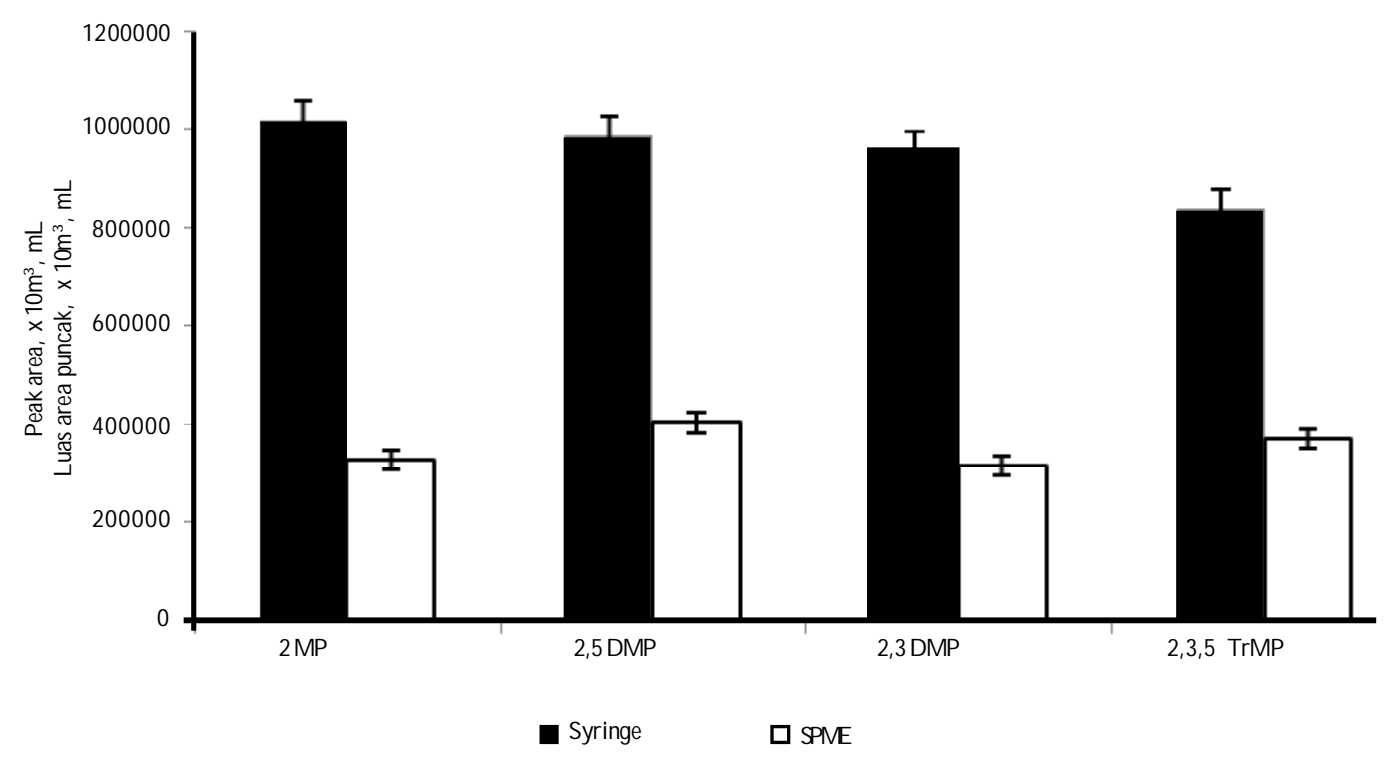

Figure 5. Comparison of peak area of four pyrazines extracted by syringe dan SPME.

Gambar5. Perbandingan luas area empat pirazin yang diekstrak dengan syringe dan SPME.

pyrazine have boiling point of $155^{\circ} \mathrm{C}$, while 2,3,5-trimethyl pyrazine has boiling point of $171^{\circ} \mathrm{C}$ (Burdock, 2005).

M ost of pyrazines underwent loss of quantity during heat treatment, as occurred in pyrazine, 2-M P , 2,5-DM P, 2,3-DM P and acetylpyrazine (F igure 7). Significant loss was found in 2,5-DM P and ACP, where the compounds were almost eliminated. Slight reductions were found in pyrazine and 2-M $P$, which the final amount was is somewhat less than it was.

Instead of heat loss, TM P and TrM P underwent increasing quantity at higher temperature. TrM P was suggested being synthesized during heat treatment, as being showed by gradual supplementation. Additional TM P was detected in $70^{\circ} \mathrm{C}$, after minor reduction in $60^{\circ} \mathrm{C}$.

\section{Extraction of C ocoa V olatile Compounds by using SPME}

Detection of other volatile compounds in cocoa bean extracted by SPM E was performed using GC-M S. Complete separation of cocoa aroma chromatograms were obtained during running time for total 36 min, yet the chromatogram at 30 min running time showed small peak areas. I dentification by using GC-M S library showed that the major peaks were acetic acid, tetramethyl pyrazine, 3-methyl pentanoic acid and 2,3-dimethyl oxirane exposed at retention time (RT) of 17.54, 18.26, 22.52 and $25.99 \mathrm{~min}$, respectively. Other volatile compound such as dodecanoic acid (RT 26.12), benzene-acetaldehyde (RT 28.59) and 1,4-bis (morpholinoacetyl)piperazine (RT 32.70) were detected in small peak areas. 


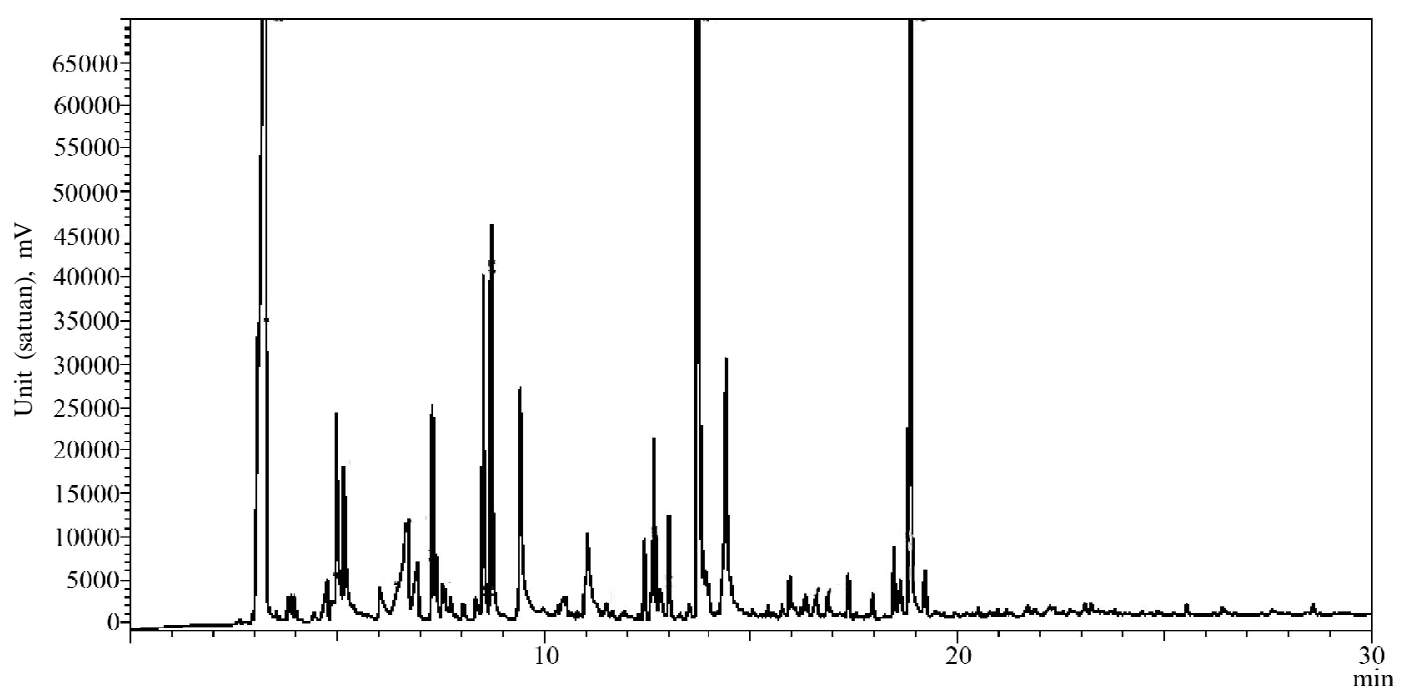

Figure 6. Chromatogram of cocoa butter, headspace extraction in $70^{\circ} \mathrm{C}$.

Gambar 6. Kromatogram sernyawa volatil lemak kakao, ekstraksi headspace pada $70^{\circ} \mathrm{C}$

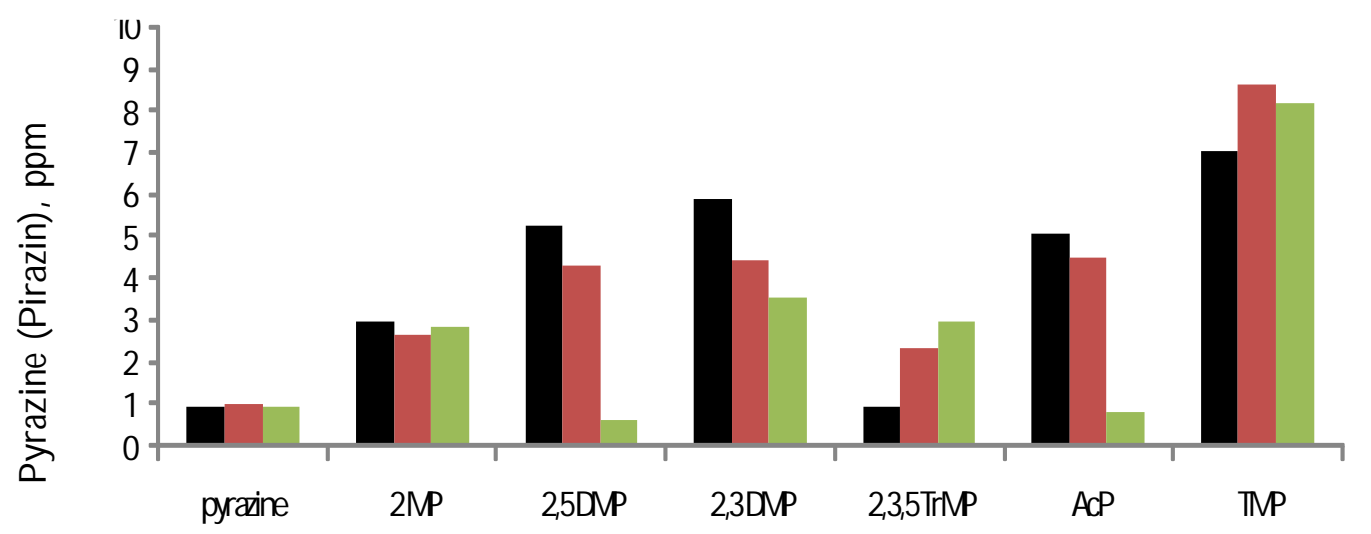

$-50^{\circ} \mathrm{C}=60^{\circ} \mathrm{C} \quad-70^{\circ} \mathrm{C}$

Figure 7. Effect of extraction temperature on seven pyrazine compounds.

Gambar 7. Pengaruh suhu ekstraksi terhadap konsentrasi 7 senyawa pirazin.

A nalysis showed that 36 compounds were detected in fermented cocoa liquor volatile compounds which representing alcohols, carboxylic acids, aldehydes, ketons, esters, pyrazines, amines and other volatile compounds ( $T$ able 2 ). They were most volatile compounds associated in fermented cocoa aroma. Frauendorfer and Schieberle (2006) identified 35 most active compounds from cocoa powder extract off however Jinap et al. (1998) stated that the main aroma compounds contribute to chocolate

Pe Lita Perkebunan, Volume 27, Nomor 1, Edisi April 2011 
Table 2. V olatile compounds of cocoa beans extracted by SPM E

Tabel 2. Senyawa volatile dari biji kakao yang diekstrak menggunakan SPME

\begin{tabular}{|c|c|c|c|}
\hline $\begin{array}{l}\text { Volatile compounds } \\
\text { Senyawa volatil }\end{array}$ & Coresponding odour & $\begin{array}{c}\text { Volatile compounds } \\
\text { Senyawa volatil }\end{array}$ & Coresponding odour \\
\hline Alcohol (Alkohol) & & Ester & \\
\hline 2,3-Butanediol & sweet, creamy & $\begin{array}{l}\text { 1-Butanol, 3-methyl-, } \\
\text { acetate }\end{array}$ & $\begin{array}{l}\text { lemon-like, flowery, } \\
\text { sweet, fruity }\end{array}$ \\
\hline Phenylethyl A Icohol & $\begin{array}{l}\text { caramel-like, alcohol-like, } \\
\text { sweet }\end{array}$ & $\begin{array}{l}\text { A cetic acid, 2-phenylethyl } \\
\text { ester }\end{array}$ & cereal-like, roasted cocoa \\
\hline Cyclobutanol & roasted cocoa & Propanol, methoxy-, acetate & flowery, green \\
\hline 2-N onanol & no smell & $\begin{array}{l}\text { Benzeneacetic acid, ethyl } \\
\text { ester }\end{array}$ & nutty, bean-like \\
\hline 2-H eptanol & no smell & D ecanoic acid, ethyl ester & nutty \\
\hline $\begin{array}{l}\text { 1,6-0 ctadien-3-ol, 3,7- } \\
\text { dimethyl- }\end{array}$ & bean-like & D odecanoic acid, ethyl ester & sweet, creamy \\
\hline Carboxylic acid & & Propanol, methoxy-, acetate & no smell \\
\hline A cetic acid & sour, nutty & Octanoic acid, ethyl ester & alcohol-like \\
\hline $\begin{array}{l}\text { Pentanoic acid, 3- } \\
\text { methyl- }\end{array}$ & sweet, rancid & Pyrazines & \\
\hline Octanoic A cid & sweet, chocolate-like & Pyrazine, trimethyl- & $\begin{array}{l}\text { sweet, nutty, bean-like, } \\
\text { smoky }\end{array}$ \\
\hline n-H exadecanoic acid & no smell & Pyrazine, tetramethyl- & $\begin{array}{l}\text { bean-like, chocolate, } \\
\text { rancid }\end{array}$ \\
\hline $\begin{array}{l}\text { Butanoic acid, 3-methyl- } \\
\text { Aldehyde }\end{array}$ & sour & $\begin{array}{l}2,3 \text { - D i m e t h y I - } 5 \text { - } \\
\text { ethylpyrazine } \\
\text { 2,3,5-Trimethyl-6- }\end{array}$ & $\begin{array}{l}\text { roasted cocoa } \\
\text { no smell }\end{array}$ \\
\hline Benzaldehyde & bean-like & ethylpyrazine & \\
\hline $\begin{array}{l}\text { Benzeneacetal dehyde, } \\
\text { alpha ethylidene- }\end{array}$ & $\begin{array}{l}\text { caramel-like, smooky, } \\
\text { nutty }\end{array}$ & $\begin{array}{l}\text { A mines } \\
1,4- \\
\text { Bis(morpholinoacetyl) }\end{array}$ & caramel-like, sweet \\
\hline $\begin{array}{l}\text { 5-M ethyl-2-phenyl-2- } \\
\text { hexenal } \\
\text { Keton }\end{array}$ & roasted cocoa & $\begin{array}{l}\text { piperazine } \\
7 \mathrm{H}-\mathrm{P} \text { y r r o I o ( } 2,3 \text { - } \\
\text { d)pyrimidin- }\end{array}$ & $\begin{array}{l}\text { caramel-like } \\
\text { citrus-like }\end{array}$ \\
\hline $\begin{array}{l}\text { Ethanone, 1-(1H-pyrrol- } \\
\text { 2-yl)- } \\
\text { Cyclobutanone, 2-ethyl- }\end{array}$ & $\begin{array}{l}\text { sweet, caramel-like, } \\
\text { honey- like, nutty } \\
\text { no smell }\end{array}$ & $\begin{array}{l}\text { 4-amine } \\
\text { 1,2-Propanediamine } \\
\text { Other volatiles }\end{array}$ & smoky \\
\hline $\begin{array}{l}\text { 2-Butanone, 3-hydroxy- } \\
\text { 2-Nonanone }\end{array}$ & $\begin{array}{l}\text { no smell } \\
\text { no smell }\end{array}$ & $\begin{array}{l}\text { Oxirane, 2,3-dimethyl-, } \\
\text { trans- } \\
\text { Propane, 2-(ethenyloxy)- } \\
\text { Hydrazine, 1, 1-dimethyl- }\end{array}$ & $\begin{array}{l}\text { caramel-like } \\
\text { roasted cocoa }\end{array}$ \\
\hline
\end{tabular}

flavor are pyrazine, carbonyl, ester, alcohol, hydrocarbon and phenol.

This result also implies that cocoa bean aroma is characterized by presence of sweet, caramel-like, nutty and bean-like odour. Those odours are expressed by pyrazines, ethyl ester and alcoholic compounds, particularly trimethylpyrazine, tetramethylpyrazine, 2,3-butanediol, dodecanoic acid, phenylethyl alcohol, ethanone, benzeneacetal-dehyde and 1,4-bis (morpholinoacetyl) piperazine. Few unusual odours might also present, for instance rancid and lemon-like that came with 1-Butanol, 3methyl-, acetate and 3-methyl-pentanoic acid.

\section{CONCLUSION}

SPM E offers accurate, easier extraction technique, shorter extraction time and to extract specific compounds with lower extraction temperature. Selection can be made by choosing the type and fiber specification. SPM E extracted pyrazine was adequate and well detected in a gas chromatography system equipped either with FID or M ass Spectrometry detector. Over thirty compounds were detected as the most representative volatile-semi volatile compounds from roasted cocoa beans including 2 methyl pyrazine (2M P); 2,3 and 2,5 di-methyl pyrazine (DMP); and 2,3,5 trimethyl 
Pyrazine (TrM P) were identified. Alcohols, carboxylic acids, aldehydes, ketons, esters, pyrazines, amines and other volatile compounds were also extracted and associated to chocolate aroma. The presence of other volatile compounds which are the key contributor to chocolate aroma indicates SPM E extraction is applicable in aroma analysis. Limiting factor for SPM E is in quantity of compound trapped from the extraction which is lower than that of resulted from syringe injection.

\section{REFERENCES}

Brunetto, M .R.; Y.D. Cayama; L. Gutiérrez; S.C. Roa; Y.C. M endez; M.Gallig-nani; A. Zambrano; A. Gomez \& G. Ramos (2009). H eadspace has chromatography-mass spectrometry determination of alkylpyrazines in cocoa liquor samples. Food chemistry, 112, 253257.

Berlardi \& J. Pawliszyn (1989). The application of chemically modified fused silica fibers in the extraction of organics from water matrix samples and their rapid transfer to capillary columns. Water Pollution Research J ournal of Canada, 24, 179-191.

Bonvehi, J.S. \& F. V. Coll (2002). Factors affecting the formation of alkyl-pyrazines during roasting treatment in natural and alkalized cocoa powder. J ournal of Agricultural and Food Chemistry, $50,3743-3750$.

Burdock, G. (2005). Fenaroli's Handbook of Flavor Ingredients $5^{\text {th }}$ (Ed.). New Y ork: CRC Press.

Counet, C.; D. Callemien; C. Ouwerx \& S. Collin (2002). U se of gas chromatographyolfactometry to identify key odorant compounds in dark chocolate, comparison of samples before and after conching. J ournal of Agricultural and Food Chemistry, 50, 2385-2391.
Da Silva, G.A.; F. A ugusto \& R.J. Poppi (2008). Exploratory analysis of the volatile profile of beers by HS-SPME. Food Chemistry, 111, 1057-1063.

Ducki, S.; J. M iralles-Garcia; A. Zumbé; A. Tornero \& D. M. Storey (2008). Evaluation of solid-phase micro-extraction coupled to gas chromatography-mass spectrometry for the headspace analysis of volatile compounds in cocoa products. Talanta, 74, 1166-1174.

Frauendorfer, F. \& P. Schieberle (2008). Changes in key aroma compounds of criollo cocoa beans during roasting. Journal of Agricultural and Food Chemistry, 56, 10244-10251.

Frauendorfer, F. \& P. Schieberle (2006). I dentification of the key aroma compounds in cocoa powder based on molecular sensory correlations. J ournal of Agricultural and Food Chemistry, 54, 5521-5529.

Hashim, I. \& H. Chaveron (1994). Extraction and determination of methyl-pyrazines in cocoa beans using coupled steam distillation-micro-distillator. Food Research International, 27, 537-544.

Górecki, T.; X. Y u \& J. Pawliszyn (1999). Theory of analyte extraction by selected porous polymer SPME fiber. The Analyst, 124, 643-649.

Jinap, S.; W.I. W an Rosli; A.R. Russly \& L.M . Nurdin (1998). Effect of roasting time and temperature on volatile components profile during nib roasting of cocoa beans (Theobroma cacao). J ournal of the Science and Food Agriculture, 77, 441-448.

Krings, U.; K. Zelena; S. Wu \& R.G. Berger (2006). Thin-layer high vacuum distillation to isolate volatile flavor compounds of cocoa powder. European Food Research Technology, 223, 675681.

Kumazawa, T.; H. Seno; X. Lee; A. Ishii; K. Watanabe-Suzuki; K. Sato \& O. Suzuki 
(1999). Extraction of methyl-xanthines from human body fluids by solid phase microextraction. Analitica Chimica Acta, 387, 53-60.

M arsili, R. (2002). Flavor, Fragrance and Odor Analysis. New York: Marcell and Decker Inc.

M isnawi, S. Jinap; B. Jamilah \& S. N azamid (2004). Effect of polyphenol concentration on pyrazine formation during cocoa liquor roasting. Food Chemistry, 85, 73-80.

Pawliszyn, J.; B. Pawliszyn \& M. Pawliszyn (1997). Solid phase microextraction (SPME), The Chemical Educator 1 vol. 2 no. 4. New Y ork: Springer-V erlag.

Perraudin, F.; J. Popovici \& C. Bertrand (2006). A nalysis of headspace-solid micro-extracts from flowers of Maxillaria tenuifolia Lindl. by GC-M S. Electronic Journal of Natural Substances, 1 , 1-5.

Schult, T.H.; R.A. Flath; T.R. M on; S.B. Eggling $\&$ R. Terranishi (1977). Isolation of volatile components from a model system. J ournal of Agricultural and Food Chemistry, 25, 446-448.

Shirey, R.E. \& L.M . Sidisky (1999). Analysis of Flavors and $O$ ff-flavors in Foods and beverages using SPM E. USA : Supelco.

Shirey, R.E. (1999). Polyacrylate film fiber for solid phase microextraction of polar semivolatilesfrom water. The Reporter, $14,6-7$.

Supelco (1998). Chromatography Products for Analysis and Purification. USA: SigmaAldrich.

Vazquez-L andaverde, P.A.; G. Velazquez; J.A.Torres \& M.C. Qian (2005). Quantitative determination of thermally derived off-flavor compounds in milk using solid-phase micro- extraction and gas chromatography. J ournal of Dairy Science, 88, 3764-3772.

Vilchez, J.L.; A. Prieto; L. Araujo \& A. Navalon (2001). Determination of fipronil by solid phase microextraction and gas chromatography-mass spectrometry. J ournal of Chromatography, 919, 215222.

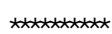

